\title{
Does Paying for Aquatic Resources Matter? A Case of an African Riverine Ecosystem
}

\author{
Gladys Chigamba ${ }^{1, *}$, Moses Limuwa ${ }^{1}$ (D) and Emmanuel Kaunda ${ }^{2}$ \\ 1 AquaFish Centre of Excellency, Lilongwe University of Agriculture and Natural Resources (LUANAR), \\ Lilongwe 265, Malawi; mlimuwa@luanar.ac.mw \\ 2 NEPAD Fish Node, AquaFish Centre of Excellency, LUANAR, Lilongwe 265, Malawi; ekaunda@yahoo.com \\ * Correspondence: glachigamba@yahoo.com
}

Citation: Chigamba, G.; Limuwa, M.; Kaunda, E. Does Paying for Aquatic Resources Matter? A Case of an African Riverine Ecosystem. Sustainability 2021, 13, 4177. https://doi.org/10.3390/su13084177

Academic Editor: Ashraf Dewan

Received: 27 January 2021

Accepted: 6 March 2021

Published: 9 April 2021

Publisher's Note: MDPI stays neutral with regard to jurisdictional claims in published maps and institutional affiliations.

Copyright: (c) 2021 by the authors. Licensee MDPI, Basel, Switzerland. This article is an open access article distributed under the terms and conditions of the Creative Commons Attribution (CC BY) license (https:/ / creativecommons.org/licenses/by/ $4.0 /)$.

\begin{abstract}
Valuation of environmental goods and services has an important role to play in the protection and conservation of riverine resources. However, the literature shows a dearth of information regarding factors that influence people's willingness to pay (WTP) for riverine resources. This research study was undertaken to find out key factors that affect the willingness of people to pay for the conservation of aquatic resources in the lower section of the Linthipe River in Malawi. Data was collected through household interviews, focus group discussions, key informant interviews, and contingent valuation (CV) surveys. The study noted that communities were willing to offer $\$ 3.51$ per year for the conservation of aquatic resources in the river. This study established that the people's WTP is a function of education level, household usage of the goods and services, community support in the management of the resources, household income, and distance of the household from the river ecosystem. The study further discovered that the pay-out level of the users along the Linthipe River was driven by household usage of resources from the river, period of stay in the area, and level of household income. Our recommendation is that government and development partners should popularize the important role played by rivers and streams to surrounding communities and beyond to appeal for more support from users. The authorities must further empower the communities along the rivers and streams to sustainably manage the aquatic resources for the continued appreciation of aquatic resources by future generations.
\end{abstract}

Keywords: willingness to pay; Linthipe River; contingent valuation; Heckman two-stage model

\section{Introduction}

The world is increasingly challenged by rampant practices of deforestation, degradation of water resources, declining fisheries, limited institutional capacity to manage natural resources, and farming practices that lead to soil erosion and reduced fertility, among other things. In an attempt to address these challenges, policy and decision-makers propose environmental valuation as a technique to appeal for support towards conservation and sustainable utilization of natural resources [1]. It is modelled that integration of environmental values into all development planning processes at the national and local level could be a precursor for the socio-economic development of a country.

Environmental values are, among other things, generated through the assignment of values to environmental goods and services. Commonly, users of the goods and services are asked about the amount they would be willing to pay (WTP) to continue enjoying environmental benefits [2]. In other words, valuation attempts to ascertain how much worse off would users be as a result of the degraded state of natural resources. However, the valuation of environmental goods and services varies from one user to the other [3]. For instance, people with low-income levels may offer a low amount towards conservation of natural resources compared to those with medium and high-levels [1,4].

This study was designed to establish the factors that influence the economic valuation of aquatic resources in the lower section of the Linthipe River. For this study, the aquatic 
resources constituted surface waters and the habitat they provide, including both plant and animal communities. These resources generate important goods and services that are essential for the livelihoods of the people along the Linthipe River. The goods and services include water for drinking, fishing, and bathing; crop cultivation; habitat for animals; sand mining; and cultural and religious purposes, among other things.

The Linthipe River is one of the major inlets of Lake Malawi. The availability and quality of water from the river has a strong bearing on the survival of the aquatic life in Lake Malawi. The river also serves as a breeding ground for endemic endangered species of Opsaridium microlepsis (Mpasa) and Labeo mesops (Ntchila). These fish species have high economic value because they fetch better prices on the market. Opsaridium microlepsis is principally caught during seasonal breeding migration from Lake Malawi into the Linthipe River. Most of the fish that migrate from lakes to rivers to reproduce, such as Opsaridium microlepsis and Labeo mesops, are declining [5-7]. Several factors might have contributed to the decline of fish species in the Linthipe River. Among other things, Mahlatini et al. [8] identified the undervaluing of aquatic resources as a key factor for the continued decline of aquatic resources, including fish species.

Whilst studies have been conducted elsewhere on the valuation of natural resources, there are no studies that have been undertaken in Malawi to establish the key factors that would affect the willingness of users to pay for the conservation of rivers and streams in Malawi. Most of the riverine studies in Malawi have focused on the general management of the river ecosystem [9-11]. None of the studies attempted to link economic pricing theory to quantitative and monetary values of aquatic resource, let alone find the reasons behind the valuation. The understanding of the economic values of the Linthipe River may help users to deepen their appreciation of riverine resources and could motivate them to take extra care of the resources. The reasons behind the valuation of the riverine resources would also help policymakers and development partners to appropriately provide concrete policy direction on the conservation of natural resources along the Linthipe River. This study was commissioned to ascertain whether payment of aquatic resources matters at all.

\section{Literature Review}

Rivers and streams have an undeniably critical role to play in sustaining humans and wildlife in the ecosystem. However, the big question is why rivers and streams are continuously being degraded and cared for less. One of the possible answers for this could be that people do not believe that water resources need to be conserved and sustainably utilized [12]. It may also imply that people do not appreciate the intrinsic value that lies in the water resources, let alone attempt to estimate the non-market value of the aquatic resources as a mechanism for seeking public attention.

Assigning an economic value to the natural resources has the potential to guide users to choose wisely among the competing uses of natural resources. Ultimately, this may contribute to greater human satisfaction and improved human welfare. The value may also be an important basis for policy and decision-makers to justify environmental programming and increased resource allocation [13,14].

The valuation of the rivers and streams depends on the goods and services they generate. Goods and services with market value are easier to measure, while those without market prices may involve complicated methods for estimating the economic value [15]. In practice, most of the goods and services that rivers and streams offer have no market value, rendering it difficult for policy and decision-makers to economically justify development decisions on resource allocations.

The valuation of the goods and services generated from the rivers and streams cannot be standardized. They may be varied differently from one user to the other, with some attaching higher values than others. Studies have been undertaken to establish the reasons behind the willingness to pay and payout level for the river generated resources. The studies have revealed different factors that may influence the willingness to pay for the conservation of aquatic resources, but the level of significance of those factors depends on 
the nature of the rivers and streams being measured. For instance, Wattage and Mardle [16] reported that the bid value and expectation of future use for the aquatic resources are critical in influencing individuals' WTP. On the contrary, Moffat et al. [17] challenged that the bid value tends to have a negative impact on the WTP because it may not be a true value of what could have been offered willfully. Wattage and Mardle [16] and Janet et al. [18] observed that the level of household income may not proportionately imply a high willingness to pay. However, other studies documented that household income may positively influence one's willingness to pay for natural resources. Prasher et al. [19] and Do and Bennett [20] added that distance between the users and the natural resource can significantly influence one's WTP - thus, the closer the user to the natural resource, the higher the WTP. Other factors that have been documented to have a positive influence on the WTP include educational level, age, and knowledge about natural resource $[19,21]$.

Measurement of WTP for both use and non-use values of rivers and streams is commonly estimated through the Contingent Valuation Method (CVM) [13,22,23]. The CVM can measure the value that a person places on goods or on a service. Through the CVM, users are asked hypothetical questions to indicate the amount they would be willing to pay for the improvement of goods or services. Alternatively, the users are asked to indicate the amount they would be willing to forego to sustain the existing service currently being enjoyed [24]. The CVM creates a hypothetical marketplace in which no actual transactions are made and commodities cannot be exchanged in a regular market. It is called contingent valuation because people are asked to state their WTP contingent on a specific hypothetical market [25]. The CVM was the most appropriate method for the study as it helped to estimate the non-market value of the various goods and services generated from the Linthipe River. Particularly, the study established the reasons and driving factors that influence the willingness of the communities living along the Linthipe River to pay for the conservation of the river.

\section{Data and Methods}

\subsection{Study Area}

The research study was conducted along the Linthipe River catchment in Salima District (Figure 1). The Linthipe River lies on $13^{\circ} 55^{\prime} 0^{\prime \prime} \mathrm{S}$ latitude and $34^{\circ} 34^{\prime} 18^{\prime \prime}$ E longitude. It has a basin area of $8560 \mathrm{~km}^{2}$ [8]. The river originates from the Dzalanyama Range, and the river basin extends to the Dedza Mountain. The basin covers the Dedza, Dowa, Lilongwe, and Salima Districts. The Salima district is among the top six districts in Malawi that are very vulnerable to climate change impacts. The district has a tropical wet and dry climate with a pronounced warm, windy, and mostly clear dry season. On November 2, typically the hottest day of the year, temperatures in the Salima district typically range from $77^{\circ} \mathrm{F}\left(25^{\circ} \mathrm{C}\right)$ to $91^{\circ} \mathrm{F}\left(32.8^{\circ} \mathrm{C}\right)$, while on July 3 , typically the coldest day of the year, they range from $62^{\circ} \mathrm{F}\left(16.7^{\circ} \mathrm{C}\right)$ to $79{ }^{\circ} \mathrm{F}\left(26.1^{\circ} \mathrm{C}\right)[26,27]$. The district is characterized by three major seasons, which include the cool dry season (May to August), the warm wet season (November to April), and the hot dry season (September to October), with annual rainfall averaging $860 \mathrm{~mm}$ to $1400 \mathrm{~mm}$ [28].

\subsection{Study Design and Sampling}

The study applied a longitudinal sampling design in which panel data was gathered from the respondents in the same sampling sites twice a year. Specifically, data was obtained in both dry and wet seasons to allow observations of multiple phenomena within a year. The study began with a reconnaissance survey to assess the potential of the study site to provide adequate information for estimating the economic value of the aquatic resources in the Linthipe River. A cross-sectional mixed method research design was adopted. The design was considered appropriate as it allows the use of various methods to gather quantitative and qualitative data [29,30]. 


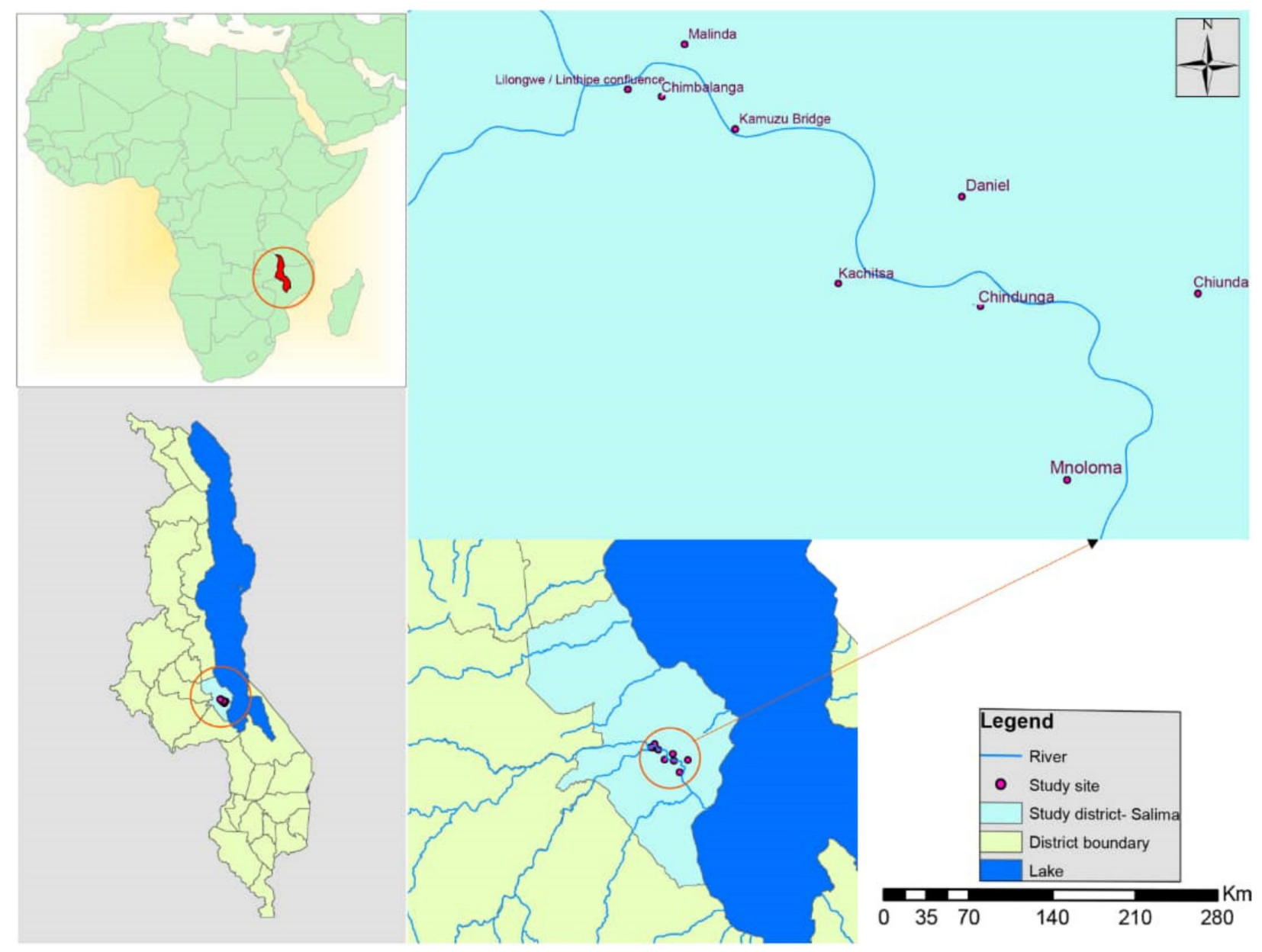

Figure 1. Geographical Location of the Linthipe River catchment area in Malawi (Source: Authors, ArcGIS 10.6).

The respondents for the study were identified through a stratified random sampling technique. Stratified random sampling is widely used and very useful when the target population is heterogeneous [31]. In this study, the households were stratified as either a closer stratum or further away stratum, depending on proximity to the river. From each stratum, several villages were randomly picked, and their households grouped to form a household stratum [32]. The questionnaire had open and closed questions from which data were collected on people's uses, their willingness to pay for the goods and service, and the factors affecting their willingness to pay. Field observations and market pricing were used to complement and supplement data. To offset some expected limitations, some values provided by households were triangulated with data from government officers.

\subsection{Study Tools}

A reconnaissance survey within the study area was conducted from 5 th to 11 th October 2019. Men and women were interviewed separately to capture the general perception of communities towards the valuation of the Linthipe River. Interviews were also extended to Agricultural Development Extension staff, Fisheries officers, Forest officers, and lead farmers. The interviewees were asked about the general information of the study area to inform the design of the methodology and the approach of the research study. The survey helped in the appreciation of the physical features and pattern of the Linthipe River and also gather preliminary input of district and community stakeholders on the planned research study.

Household interviews were directed to 391 respondents, of which 117 users were located at least one kilometer away from the river $(t>30 \%)$. The respondents provided 
information about the aquatic resources available in the Linthipe River, respondents' socioeconomic status, WTP, and pay-out levels, along with associated reasons. Open- and close-ended questions were used in the questionnaire. Before the interview, interviewees were briefed on the nature of the study and informed about the confidentiality of the information they were to provide. All the data was programmed in Open Data Kit (ODK) for mobile data collection.

Key informant interviews (KIIs) were done with over 30 knowledgeable individuals, who provided relevant information, ideas, and insights [33-35] on various aspects related to the aquatic resources in the Linthipe River. The interviews were held at community and district levels. At the district level, the researcher interviewed District Council officials, officials from the Ministries of Agriculture and Fisheries, and Non Governmental Organisations (NGOs) undertaking natural resource and forestry projects in the study district. At the community level, key informants included the Traditional authority, Area Development Committee (ADC) members, Village Development Committee (VDC) members, elders, youths, religious leaders, and opinion leaders.

Focus Group Discussions (FGDs) were done with 20 groups of community members engaged in different livelihood activities along the Linthipe River. The number of participants per FGD session was within the recommended range of between eight and fifteen participants, as suggested by scholars [36]. The participants provided detailed insight into the historical pattern of the Linthipe River, different goods and services generated from the river, and general importance associated with the Linthipe River.

Participant observation was undertaken during the field survey as a data-gathering technique to complement information collected through other tools such as KIIs, FGDs, and household questionnaires. The researcher made careful, objective notes about what was heard, recording all accounts and observations in as much detail as possible. The tool was useful for gaining an understanding of the physical, social, cultural, and economic contexts in which study participants live; the relationships among and between people, contexts, ideas, norms, and events; and people's behaviors and activities.

\subsection{Analytical Framework}

The study used Heckman's Two-Stage Model to determine factors affecting respondents' willingness to pay and pay-out levels for the conservation of the resources in the Linthipe River. The model is relevant for the WTP concept because it makes a combined statistical analysis of WTP and pay-out level with respect to the associated reasons [37]. Heckman's two-stage model also helps to effectively correct the selectivity deviation, which is a common problem when estimating selected subsamples in econometric analysis [38].

The ecological compensation payment activities of communities were divided into two stages. The first stage was the behavioral decision stage, where community members surrounding the Linthipe River decided whether they should pay or not for the conservation of the river. Community members who were not willing to pay in stage one of the model were terminated as the object of the next phase of the study, and only those respondents who were willing to pay entered the second stage of the model.

The second stage is the decision-making stage, where the surrounding communities who are willing to pay for the environmental protection of the river basin decide how much to offer. Heckman's two-stage model has two equations. The first equation is the selection equation, which determines an individual's willingness to pay. The selection equation is expressed as:

$$
W_{i}=\propto Z_{i}+\varepsilon_{i} \quad i=1, \ldots, N
$$

where $\mathrm{W}$ is a binary dependent variable taking the value of 1 if the individual is willing to pay and 0 if the individual is not willing to pay, $Z$ is a vector of explanatory variables, and $\varepsilon$ is the error term.

The second equation, which determines the payout level, is the linear model of interest and is expressed as:

$$
Y_{i}=\beta_{1}+\beta_{2} X_{i}+\mu_{i} \quad i=1, \ldots, n N>n
$$


where $Y$ is the payout level, $X$ is a vector of explanatory variables, and $\mu$ is the error term. A selection bias arises when $Y_{i}$ is observed only when $Z_{i}=1$, and if the errors $\left(\varepsilon_{i}\right.$ and $\left.\mu_{i}\right)$ of the two equations are correlated. In such situations, the usual least squares estimators of $\beta_{i}$ are biased and inconsistent. To correct this problem, in the first equation, the inverse mills ratio is generated and fed into the second equation as an additional regressor.

The first equation is estimated using probit regression as:

$$
\operatorname{Pr}\left(Y_{i} \text { observed } \mid Z_{i}\right)=\Phi\left(\propto Z_{i}\right)
$$

From the estimated probabilities, the inverse mills ratio for each observation is obtained as:

$$
M_{i}=\frac{\phi\left(\hat{\alpha} Z_{i}\right)}{\Phi\left(\hat{\alpha} Z_{i}\right)}
$$

where $\phi$ is the normal density. This is then augmented in the second equation as:

$$
Y_{i}=\beta_{1}+\beta_{2} X_{i}+\beta_{m} M_{i}+\mu_{i} \quad i=1, \ldots, n N>n
$$

The least square estimation of this equation yields consistent estimators of $\beta_{i}$ free of estimation bias.

\section{Results and Discussions}

\subsection{Socio-Economics and Household Characteristics}

Table 1 presents the descriptive statistics for households involved in the study. The majority of the household heads around the Linthipe River were adults aged, on average, 40.8 years. Their average household size of 5.3 was large compared to the national average of 4.4 [27], which implied relatively huge family responsibility [39]. It was also revealed that $76.1 \%$ of the sampled households reside close to the river (less than $1 \mathrm{~km}$ from the river). Their proximity to the Linthipe River may imply more dependency on the river resources.

The results have also shown that the majority of the household heads along the Linthipe River were males (74.4\%), compared to female-headed households $(25.6 \%)$. In terms of marital status, $71 \%$ of the respondents were reportedly married, $12 \%$ were divorced, $11 \%$ widowed, $4 \%$ single, and $2 \%$ polygamous. According to FGDs and key informant interviews, men assume headship of the households regardless of their capacity to generate income for the households. Men have also overall decisions over the affairs of the households. Men's decision-making power extends to the control over community utilization of natural resources. The men's decision-making position is influenced by the socially constructed roles and values that tend to give powers to men to lead in decision making [40]. The literature suggests that the management of natural resources, such as water and fisheries, has been a challenge in Malawi due to the underfunding of policies that end up in the limited implementation of women empowerment initiatives, which are often not prioritized. [21]. The study further noted that the majority of households largely earn their living through farming $(74.8 \%)$, small business $(52.1 \%)$, and fishing $(27.9 \%)$. Such livelihood activities may affect people's perception of the aquatic resources generated from the Linthipe River.

\subsection{Estimation of WTP}

Non-use values of the Linthipe River were estimated by stated preference according to the CVM, which can also be referred to as WTP [3]. WTP was used to capture the value of non-use value and other indirect use value for the Linthipe River (i.e., water, nutrient recycling, conservation for biodiversity, etc.), which could not be quantified using market value. Households were asked to indicate how much they were willing to pay per month for the conservation of the river. A total of 245 out of 391 respondents $(62.7 \%)$ were willing to pay to conserve the aquatic resources of the Linthipe River (Table 2). 
Table 1. Socio-economic and demographic characteristics of the respondents.

\begin{tabular}{|c|c|c|}
\hline Variable & Category & Results \\
\hline \multirow{2}{*}{ Gender of Respondents } & Male & $74.3 \%$ \\
\hline & Female & $25.7 \%$ \\
\hline \multirow{2}{*}{ Type of Household head } & Male headed & $74.4 \%$ \\
\hline & Female-headed & $25.6 \%$ \\
\hline \multirow{5}{*}{$\begin{array}{l}\text { Marital status of the } \\
\text { household head }\end{array}$} & Single & $4 \%$ \\
\hline & Married & $71 \%$ \\
\hline & Polygamy & $2 \%$ \\
\hline & Divorced & $12 \%$ \\
\hline & Widow & $11 \%$ \\
\hline Mean Age of household head & & 40.8 \\
\hline \multirow{4}{*}{ Educational level } & None & $21.2 \%$ \\
\hline & Primary & $71.9 \%$ \\
\hline & Secondary & $5.6 \%$ \\
\hline & Adult education & $1.3 \%$ \\
\hline Household income (\$) & Average annual income & 189.86 \\
\hline \multirow{2}{*}{ River to house distance } & Less than $1 \mathrm{~km}$ & $76.1 \%$ \\
\hline & More than $1 \mathrm{~km}$ & $23.9 \%$ \\
\hline \multirow{6}{*}{ Main occupation } & Farming & $74.8 \%$ \\
\hline & Business & $52.1 \%$ \\
\hline & Fishing & $27.9 \%$ \\
\hline & Sand mining & $21.7 \%$ \\
\hline & Casual work & $9.4 \%$ \\
\hline & Employment & $1.8 \%$ \\
\hline Mean household size & $\ldots$ & 5.3 \\
\hline
\end{tabular}

Table 2. Mean Willingness to Pay (WTP) Analysis (US\$1 = MK735.00).

\begin{tabular}{cccccc}
\hline Parameter & N & Percent & $\begin{array}{c}\text { Mean WTP } \\
(\text { MK) }\end{array}$ & $\begin{array}{c}\text { Min. WTP } \\
(\text { MK) }\end{array}$ & $\begin{array}{c}\text { Max. WTP } \\
(\text { MK) }\end{array}$ \\
\hline \multirow{2}{*}{ Amount } & 245 & 62.7 & $\begin{array}{c}2576.73 \pm \\
404.05(\$ 3.51)\end{array}$ & $100.00(\$ 0.14)$ & $\begin{array}{c}50,000.00 \\
(\$ 68.11)\end{array}$ \\
\hline
\end{tabular}

The proportion of households' WTP $(62.7 \%)$ is broadly consistent with the trends obtained by Makwinja et al. [21], in which 57.4\% were willing to improve the water quality from Chia Lagoon. Liu et al. [41] reported a 53\% rate of WTP for improved air quality in China. Bennett et al. [42] recorded a response rate of $47.3 \%$ for WTP in Australia. Interestingly, some communities expressed higher willingness to pay towards the conservation of natural resources. For instance, Zuze [15] found 98\% for the valuation of Lake Chiuta Wetland, while Birdira et al. [43] reported 92\% WTP for the improvement of beaches in Mersin, Turkey.

In terms of how much the communities were willing to pay for the conservation of the Linthipe River, the study noted that, on average, users along the Linthipe River were willing to pay $\$ 2.1967$ towards the conservation of the river (Table 3). 
Table 3. Pay-out level in USD for community members along the Linthipe River.

\begin{tabular}{cccccc}
\hline Variable & N & Min & Max & Mean & Std. Dev \\
\hline Men & 130 & 0.00 & 68.03 & 2.51 & 7.67 \\
Women & 261 & 0.00 & 68.03 & 2.04 & 6.67 \\
Youths (15-35yrs) & 216 & 0.00 & 68.03 & 2.09 & 6.36 \\
Adults (above 35yrs) & 175 & 0.00 & 68.03 & 2.33 & 7.77 \\
Residents (less than 1 KM) & 296 & 0.00 & 68.03 & 2.64 & 7.98 \\
Residents (above 1 KM) & 93 & 0.00 & 8.16 & 0.84 & 1.57 \\
All residents & 391 & 0.00 & 68.03 & 2.20 & 7.01 \\
\hline
\end{tabular}

The results further show that men (\$2.5128) expressed willingness to pay more than women (\$2.0393). The payout level reflects the gender perspective of income where men tend to have a higher income than women. Regarding the effect of age on the payout level, youths had a lower value (\$2.0899), while adults expressed a willingness to pay more (\$2.3285). This may imply that adults place more value on the river than youths, probably because most of them are engaged in farming activities along the river. As expected, residents closer to the river offered a higher amount (\$2.6372) than those living at least a kilometer away.

\subsection{Reasons behind the Willingness to Pay}

The respondents were asked to indicate the reasons behind their willingness or nonwillingness to pay for the conservation of the Linthipe River. Table 4 presents the various reasons that were provided by the respondents. The reasons were based on the perceived benefits accrued to the river. The majority of community members $(80.1 \%)$ were willing to pay for the conservation of the Linthipe River because the river provides water for agriculture, domestic purposes, building materials, and livestock. At least 6 out of 10 people reported that the river provides wild food $(60.9 \%)$ and important heritage for future generations $(63.4 \%)$. Other reasons for willingness to pay included preservation of biodiversity because the Linthipe River is a habitat for various wildlife (26\%), including the famous Opsaridium microlepsis (Mpasa) fish species.

Table 4. Reasons for WTP and non-WTP among the Respondents.

\begin{tabular}{cccc}
\hline Factor & Reason & Value & Percent \\
\hline \multirow{3}{*}{ WTP } & Provide building materials & 147 & 37.6 \\
& Conservation for future generation & 248 & 63.4 \\
& Water for Agriculture, domestic & 313 & 80.1 \\
& purposes, and livestock & 89 & 26.0 \\
& Home for wildlife (biodiversity) & 238 & 60.9 \\
Non-WTP & Provides wild food & 40 & 20.5 \\
& Nature is free & 43 & 22.1 \\
& It is the government's responsibility & 56 & 28.7 \\
& Too poor to make an offer & 31 & 15.9 \\
& Do not directly benefit from the river & 25 & 12.8 \\
\hline
\end{tabular}

The empirical evidence from the study indicates that the rate of WTP increases when the communities acquire more direct benefits from the natural resource. FGD appreciated fishing activity as an important source of income, especially for youths. "Because we don't have any other source of income, we find fishing as a way out. It gives us quick cash for meeting our basic needs" reported youths during FGDs. Adults, especially women, singled out water resources as an important treasure for their livelihood activities. This explains why at least 8 out of 10 people $(80.1 \%)$ justified their willingness to pay for the conservation of the Linthipe River based on several livelihood activities taking place along the river, such as fishing, irrigation, bathing, and washing. It was encouraging to note that 6 out of 10 people 
(63.4\%) were willing to pay for the conservation of the river. "This is the only community resource we can pass on to our children," remarked Group Village Head Maganga.

This study, however, has shown that some households were not willing to pay. About $37.3 \%$ of the respondents provided their reasons for not willing to pay. Commonly, they indicated that they were too poor to make any offer $(28.7 \%)$, others expressed that it was the government's responsibility to conserve rivers in Malawi (22.1\%), and 20.5\% felt that nature is free, hence, there was no need to pay for it. On the other hand, others explained that the Linthipe River was far away from them and, as such, offered little benefit. $12.8 \%$ expressed fears that the amount they would offer would not be used prudently. "There is too much corruption with these projects. We cannot even trust the chiefs to oversee the projects because they are also corrupt".

\subsection{Factors Affecting WTP}

To establish the factors that affect community willingness to pay, Heckman's two-stage model was employed. Table 5 reveals that the decision to pay for the aquatic resources from the Linthipe River was significantly influenced $(p=0.05)$ by education level $(p=0.006)$, whether the household uses the resources or not $(p=0.004)$, community support in the management of the resources $(p=0.000)$, household income $(p=0.010)$, and distance of the household from the river ecosystem $(p=0.010)$.

Table 5. Factors affecting WTP.

\begin{tabular}{cccc}
\hline Factor & Coefficient & Std. Error & $p$ \\
Age & -0.000074 & 0.006388 & 0.991 \\
Marital status & -0.102562 & 0.134681 & 0.446 \\
Gender & 0.207348 & 0.178154 & 0.244 \\
Period of stay of the householdin the area & 0.073026 & 0.154491 & 0.636 \\
Education level & 0.374977 & 0.136283 & $0.006^{*}$ \\
Occupation & -0.035622 & 0.042332 & 0.400 \\
Usage of the resources & -1.079022 & 0.375542 & $0.004 *$ \\
Community support & -0.771224 & 0.193799 & $0.000^{*}$ \\
Household income & $-1.41 \times 10^{-6}$ & $5.45 \times 10^{-7}$ & $0.010^{*}$ \\
Household size & 0.050584 & 0.038331 & 0.187 \\
Household distance to the river & 0.187000 & 0.019888 & $0.010^{*}$ \\
\hline
\end{tabular}
* $p=0.05$.

Educational level has a significant positive correlation with community members' WTP, which implies that the higher the member's educational level, the stronger is the willingness to pay [44]; the more years one spends schooling, the greater the understanding about the ecological importance of natural resources, resulting in having a stronger willingness to pay for conservation programs. Usage of the aquatic resources had a significant negative correlation with community willingness to pay. The study surmised that the more community members exploit the aquatic resources, particularly fish species, the scarcer the resource becomes, hence, they are less willing to pay. The study observed that community support and income levels were negatively related to community WTP. In other words, one more unit of community support and income did not trigger increased community WTP. The study established a relatively higher annual income level (\$190.09), but low willingness to pay (\$3.51). FGD revealed that communities understand the importance of the Linthipe River but have a perception that the conservation program lies within the jurisdiction of the state. Distance to the river has a stronger positive relationship with WTP. Communities who are living closer (less $1 \mathrm{~km}$ ) to the Linthipe River enjoy more benefits than those living far from the river. FGDs revealed that closer communities have more daily usage of the river for water consumption, irrigation, fishing, washing, and bathing compared to their counterparts. 


\subsection{Factors Affecting Pay-Out Level}

The study moved further to establish the factors that influenced the members to make a given offer. As can be seen in Table 6 below, the payout level is determined by whether the household uses the resources or not $(p=0.036)$, the period of stay in the area $(p=0.009)$, and the level of household income $(p=0.100)$.

Table 6. Factors that affect pay-out level.

\begin{tabular}{cccc}
\hline Factor & Coefficient & Std. Error & $p$ \\
\hline Age & -0.000004 & 0.000074 & 0.960 \\
Marital status & -0.000236 & 0.001576 & 0.881 \\
Gender & 0.000497 & 0.001981 & 0.802 \\
Period of stay of the household in the area & -0.003524 & 0.001680 & $0.036^{*}$ \\
Education level & 0.000039 & 0.001669 & 0.981 \\
Occupation & 0.000101 & 0.000474 & 0.832 \\
Usage of the resources & 0.018533 & 0.007129 & $0.009^{*}$ \\
Community support & 0.002967 & 0.003870 & 0.443 \\
Household income & $1.2 \times 10^{-9}$ & $7.8 \times 10^{-8}$ & $0.100^{* *}$ \\
Household size & 0.000033 & 0.000437 & 0.939 \\
\hline
\end{tabular}

${ }^{*} p=0.05 ; * * p=0.10$.

The factors show that period of stay for the community members was negatively correlated with the community's payout level. In other words, there being a longer period of stay along the Linthipe River does not imply that community members will pay more. Usage of the aquatic resources generated from the river and average household income was positively correlated to the payout level. Community members that greatly relied on/used the resources from the river made higher offers for the conservation of the river. Similarly, households with higher income levels expressed willingness to pay more money than low-income households. The findings correspond with Mahlatini et al. [8], Xiong et al. [44], Sylvie [45], and Lipton et al. [46], who established that households with higher disposable incomes had more income to protect and would see a benefit in improving the ecological environment of the river basin.

\section{Conclusions}

Rivers and streams in the world, including Malawi, are increasingly degrading. Among other things, the degradation is due to ignorance about the real value of the rivers and streams. Knowledge of the value of the natural resources would help users to informatively make a monetary contribution to the conservation programs. However, how much the users would offer may vary from one user to the others. The users have their reasons for expressing willingness to pay for the aquatic resources. This study has, among other things, established that fishing activities, water supply for irrigation activities and washing, and preservation for future generations are key factors driving users to pay for the conservation of the lower section of the Linthipe River. The study has also discovered divergent reasons that prevented other users from making any offer for the conservation of the river. Some people felt the conservation of nature is the responsibility of the government, and authorities are too corrupt to be entrusted with funds.

The study further established underlying factors that influence users to express willingness to pay and, more importantly, the payout level. It was observed that WTP for the Linthipe River is a function of education level, household usage, community support in the management of the resources, household income, and distance of the household from the river ecosystem. On the other hand, how much the users are willing to pay is triggered by household usage of the river resources, the period of stay in the area, and level of household income. 


\section{Recommendations}

The study recommends that local authorities intensify environmental education and awareness about the ecological value of the Linthipe River. Our empirical results show that users who acknowledged the ecological value of the Linthipe River are more willing to pay for conservation programs and have a higher payout level. Deliberate efforts should therefore be made to build on the existing community valuation and empower the local communities to take charge of the aquatic resource in the Linthipe River. Such efforts will help the surrounding communities to get back their utilities from the river and increase their income because most of the surrounding communities depend on the river for agriculture. By increasing food income, households may be stimulated to make better offers and greatly contribute towards the protection of the resources along the Linthipe River.

Author Contributions: G.C. currently studying Ph.D. in Aquaculture and Fisheries Sciences at Lilongwe University of Agriculture and Natural Resources, Malawi, designed the research, collected data, analyzed, and developed the manuscript. M.L. and E.K., from the Lilongwe University of Agriculture and Natural Resources, Malawi, were involved significantly at each stage of the manuscript writing, field scoping, and reviewing the study tools. All authors have read and agreed to the published version of the manuscript.

Funding: This research was partly funded by the AquaFish Centre of Excellency and the Malawi Government.

Institutional Review Board Statement: Ethical review and approval were waived for this study, because it had minimal interaction with participants and information obtained was anonymous.

Informed Consent Statement: Informed consent was obtained from all subjects involved in the study.

Data Availability Statement: Not applicable.

Acknowledgments: The authors wish to acknowledge the Department of Aquaculture and Fisheries Science, AquaFish Centre of Excellency- Lilongwe University of Agriculture and Natural Resources and Government of Malawi (GoM) for making this study possible and the communities for the lively participation during data collection.

Conflicts of Interest: The authors declare that there is no conflict of interest.

\section{References}

1. Hailu, F. The Economic Value of Natural and Environmental Resource; Ebooks. 2013. Available online: www.grin.com/document/ 283 (accessed on 24 January 2021).

2. Karira, W.J.; Mburu, J.I.; Guthiga, P.M. Empirical Analysis of the Environmental Benefits of Compliance with GLOBALGAP Standards Among Smallholder Farmers in Eastern and Central Kenya: An Environmental Valuation Approach. In Proceedings of the AAAE International Conference, Hammamet, Tunisia, 22-25 September 2013.

3. Mendelsohn, R.; Olmstead, S. The Economic Valuation of Environmental Amenities and Disamenities: Methods and Applications. Annu. Rev. Environ. Resour. 2009, 34, 325-347. [CrossRef]

4. Adekola, O.; Morardet, S.; de Groot, R.; Grelot, F. The economic and livelihood value of provisioning services of the Ga-Mampa wetland, South Africa; Environmental Systems Analysis Group, Wageningen UR. In Proceedings of the 13th IWRA World Water Congress, Montpellier, France, 1-4 September 2008.

5. Snoeks, J.; Darwall, W. Opsaridium microlepis. In 2006 IUCN Red List of Threatened Species; IUCN: Gland, Switzerland, 2001.

6. FAO. Economic Valuation of Water Resources in Agriculture; FAO: Rome, Italy, 2004; Available online: ftp://ftp.fao.org/agl/aglw / docs/wr27e.pdf (accessed on 26 January 2021).

7. Ndamala, C.T. Assessment of Reproductive Biology, Population Parameters and Exploitation Rates of Mpasa (Opsaridium microlepis) in Southern Lake Malawi (Linthipe River and South West Arm. Unpublished. Master's Thesis, Bunda College, University of Malawi, Zomba, Malawi, 2006.

8. Mahlatini, P.; Hove, A.; Maguma, L.F.; Chemura, A. Using Direct Use Values for Economic Valuation of Wetland Ecosystem Services. A case of Songore Wetland, Zimbabwe. GeoJournal 2018, 85, 41-51. [CrossRef]

9. Zidana, A.; Kaunda, E.; Phiri, A.; Khalil-Edriss, A.; Matiya, G.; Jamu, D. Factors Influencing Cultivation of the Lilongwe and Linthipe River Banks in Malawi. J. Appl. Sci. 2007, 7, 3334-3337. [CrossRef]

10. Matsimbe, M. Comparative Study of Two Major Tributaries of Lake Malawi: Spatial and Temporal Changes; NEPAD Fish Node: Lilongwe, Malawi, 2011.

11. Chigamba, G.; Kaunda, E.; Msukwa, A.; Kassam, D. A Comparison of Life history traits of mpasa, Opsaridium microlepis (Günther, 1864), (Pisces: Cyprinidae) from Bua and Linthipe Rivers in Central Malawi. Ind. J. Fund. Appl. Life Sci. 2012, 2, 76-88. 
12. Edward, B.B.; Acreman, M.; Duncan, K. Economic Valuation of Wetlands. A Guide for Policymakers and Planners; Ramsar Convention Bureau: Gland, Switzerland, 1997.

13. Lambert, A. Economic Valuation of Wetlands: An Important Component of Wetland Management Strategies at the River Basin Scale; Working Papers; RAMSAR Convention: Ramsar, Iran, 2003.

14. FAO. Ecosystem Services \& Biodiversity (ESB). 2020. Available online: http:/ /www.fao.org/ecosystem-services-biodiversity/ background/en/ (accessed on 24 January 2021).

15. Zuze, S. Measuring the Economic Value of Wetlands Ecosystem Service in Malawi: A Case Study of Lake Chiuta Wetland. Master's Thesis, University of Zimbabwe, Harare, Zimbabwe, 2013. Available online: ir.uz.ac.Zw/.../UZ_IWRM_ZUZE_2012-201 3_Final\%20Thesis\%20Document_Dec_1... (accessed on 12 September 2020).

16. Wattage, P.; Mardle, S. Total economic value of wetland conservation in Sri Lanka identifying use and non-use values. Wetl. Ecol. Manag. 2008, 16, 359-369. [CrossRef]

17. Moffat, B.; Motlaleng, G.R.; Thukuza, A. Households willingness to pay for improved water quality and reliability of supply in Chobe ward, Maun. Botsw. J. Econ. 2011, 8, 45-61.

18. Janet, A.R.A.; Ma Eugenina, C.B.; Hess, S.; Jazzie, D.S.C. Willingness to Pay for Watershed Protection by Domestic Water Users in Teguegarao City, Philippines; Poverty Reduction and Environment Management, Working Paper PREM07/06; Institute for Environmental Studies: Amsterdam, The Netherlands, 2007.

19. Prasher, R.S.; Negi, Y.S.; Kumar, V. Valuation and management of wetland ecosystem: A case study of Pong Dam in Himachal Pradesh. Man Dev. 2006, 28, 77-92.

20. Do, T.N.; Bennett, J.W. Willingness to pay for wetland improvement in Vietnam's Mekong River Delta. Australian Agricultural and Resource Economics Society. In Proceedings of the 51st Annual Conference, Queenstown, New Zealand, $13-16$ February 2007.

21. Makwinja, R.; Kosamu, I.B.M.; Kaonga, C.C. Determinants and Values of Willingness to Pay for Water Quality Improvement: Insights from Chia Lagoon, Malawi. Sustainability 2019, 11, 4690. [CrossRef]

22. Asafu-adjaye, J. Environmental Economics for Non-economists. In Techniques and Policies for Sustainable Development, 2nd ed.; Decision Analysis Series $N^{\circ}$; World Scientific Books: Singapore, 2005.

23. Costanza, R.; d'Arge, R.; de Groot, R.; Farber, S.; Grasso, M.; Hannon, B.; Limburg, K.; Naeem, S.; O’Neill, R.V.; Paruelo, J.; et al. The Value of the World's Ecosystem Services and Natural Capital. Nature 1997, 387, 253-260. [CrossRef]

24. Antony, J.; Rao, A. Contingent Valuation: A Review with Emphasis on Estimation Procedures. 2010. Available online: https: / / www.researchgate.net/publication/242676247 (accessed on 23 September 2020).

25. Hanley, N.; Wright, R.E.; Adamowicz, V. Using choice experiments to value the environment. Environ. Resour. Econ. 1998, 11, 413-428. [CrossRef]

26. Mkanda, F.X. Contribution by farmers' survival strategies to soil erosion in the Linthipe River Catchment: Implications for biodiversity conservation in Lake Malawi/Nyasa. Biodivers. Conserv. 2002, 11, 1327-1359. [CrossRef]

27. Government of Malawi (GoM). Salima Social Economic Profile; Salima District Council: Salima, Malawi, 2019.

28. Government of Malawi (GoM); National Meteorological Services; Ministry of Natural Resources Energy and Mining. 2019. Available online: www.metmalawi.com (accessed on 17 February 2021).

29. Bryman, A. Social Research Methods; Oxford University Press: Oxford, UK, 2001.

30. Kothari, C.R. Research Methodology-Methods and Techniques, 2nd ed.; New Age International Publishers: New Delhi, India, 2004.

31. Nickolas, S. How Stratified Random Sampling Works. 2019. Available online: www.investopedia.com (accessed on 20 October 2020).

32. Biau, D.J.; Kerneis, S.; Porcher, R. Statistics in Brief: The Importance of Sample Size in the Planning and Interpretation of Medical Research. Clin. Orthop. Relat. Res. 2008, 466, 2282-2288. [CrossRef]

33. USAID. Conducting Key Informant Interviews Tips. Performance Monitoring and Evaluation USAID Center for Development Information and Evaluation. Number 2. 1996. Available online: https:/ / pdf.usaid.gov/pdf_docs/PNABS541.pdf (accessed on 11 November 2020).

34. International Fund for Agricultural Development (IFAD). Rural Poverty Report. Overview. 2011. Available online: www.ifad. org/rpr2011 (accessed on 11 November 2020).

35. Kholongo, W.; Lambert, E.; Kaunda, E.; Katengeza, S.; Malunga, A. Key Factors That Influence Sustainability of Community Based Advocacy Groups After Phaseout of Donor Support. Int. J. Sustain. Dev. Res. 2020, 6, 73-79.

36. Masadeh, M.A. Focus Group: Reviews and Practices. Int. J. Appl. Sci. Technol. 2012, 2, 63-65.

37. Kone, S.; Bonfoh, B.; Dao, D.; Kone, I.; Fink, G. Heckman-type Selection Models to Obtain Unbiased Estimates with Missing Measures Outcome: Theoretical Considerations and an Application to Missing Birth Weight Data. BMC Med. Res. Methodol. 2019, 19, 231. [CrossRef]

38. Heckman, J.H. Sample Selection Bias. Econometrica 1979, 47, 153-161. [CrossRef]

39. Okogu, J. Family Size and Its Socio-Economic Implications on the Inhabitants of Delta State, Nigeria; Delta State University: Abraka, Nigeria, 2011.

40. Nagoli, J.A. Lake without Water Livelihood Coping Strategies during the Lake Chilwa Water Recessions in Malawi. Ph.D. Thesis, Swedish University of Agricultural Sciences Uppsala, Uppsala, Sweden, 2016.

41. Liu, R.; Liu, X.; Pan, B.; Zhu, H.; Yuan, Z.; Lu, Y. Willingness to Pay for Improved Air Quality and Influencing Factors among Manufacturing Workers in Nanchang, China. Sustainability 2018, 10, 1613. [CrossRef] 
42. Bennett, J.; Morrison, M.; Blamey, R. Testing the Validity of Responses to Contingent Valuation Questioning. Aust. J. Agric. Resour. Econ. 1998, 42, 131-148. [CrossRef]

43. Birdira, S.; Ünalb, O.; Birdir, K.; Williams, A.T. Willingness to Pay as an Economic Instrument for Coastal Tourism Management: Cases from Mersin, Turkey. Tour. Manag. 2013, 36, 279-283. [CrossRef]

44. Xiong, K.; Kong, F.; Zhang, N.; Lei, N.; Sun, C. Analysis of the Factors Influencing Willingness to Pay and Payout Level for Ecological Environment Improvement of the Ganjiang River Basin. Sustainability 2018, 10, 2149. [CrossRef]

45. Sylvie, N. An Assessment of Farmers' Willingness to Pay for the Protection of Nyabarongo River System, Rwanda. Master's Thesis, University of Nairobi, Nairobi, Kenya, 2010.

46. Lipton, D.W.; Wellman, K.; Sheifer, I.C.; Weiher, R.F. Economic Valuation of Natural Resources: A Guidebook for Coastal Resource Policymakers; NOAA Coastal Oceanic Program Decision Analysis Series No. 5; NOAA Coastal Ocean Office: Silver Spring, MD, USA, 1995. 